\title{
Fotoğrafta Alan Derinliği, Belirtisellik ve Temsil iliş̧kisi Üzerine
}

\author{
Koray DEĞiRMENCi *
}

\section{Özet}

Alan derinliği sinematik veya fotografik imgede mekânsal derinliğin odaksal derinlikle temsil edilmesidir. Teknik olarak bakıldığında alan derinliğinin objektif ve fotoğrafın nesnesi arasındaki mesafe, objektifin odak uzunluğu, kamera formatı, diyafram değeri gibi bir takım unsurlara bağlı olduğunu biliyoruz. Her ne kadar literatürde bu teknik unsurlar açısından alan derinliği ayrı bir tartışma konusu ise de bu çalışmada alan derinliği kavramının sinematik/fotografik imgenin felsefi ve estetik boyutu bağlamında incelendiği kuramlar tartışılacaktır. Literatürde alan derinliğinin mekânın sinematik temsil biçimleri açısından önemi üzerine çok farklı kuramsal tartışmalar mevcuttur. Bu makalede film kuramı bağlamındaki ilgili tartışmalardan bazıları fotografik imge bağlamında yorumlanacak ve fotografik medyumun belirtisellik özelliği açısından incelenecektir.

Anahtar Sözcükler: Fotoğraf, Sinema, Mekân, Temsil, Alan Derinliği, Belirtisellik, Perspektif.

\section{On the Relation Between Depth of Field, Indexicality and Representation in Photography}

\section{Abstract}

The notion of depth of field refers to the way in which spatial depth is represented through depth of focus in cinematic or photographic images. Technically speaking, depth of field is determined by many factors, namely the distance between the lens and the subject, the focal length of the lens, the camera format, the aperture value, etc. Although the technical aspects of depth of field have been subject to pointed empirical exploration, this article will address the debates that focus on the implications of the notion of depth of field vis-a-vis the philosophy and aesthetics of the cinematic and photographic image. The significance of depth of field with respect to the cinematic representation of space has stirred considerable controversy in extant literature. This paper will attempt to connect pertinent theoretical debates in film theory with photography through an examination of the implications of each on the indexical character of the photographic medium.

Keywords: Photography, Cinema, Space, Representation, Depth of Field, Indexicality, Perspective. 


\section{Giriş: Alan Derinliği ve Sinematik İmge}

Bu makalede fotoğrafın temel teknik unsurlarından birisi olan alan derinliği kavramı, mekansal derinlik temsili ile bu bağlamda fotoğrafın belirtisellik kavramıyla ilişkili olarak kavramsallaştırılmış olan nesnelerin temsili gibi iki farklı temsil alanında tartışımışıı. Bu iki temsil alanının fotoğrafın estetik ve ontolojik boyutları açısından paradoksal iki alanı ifade ettiği iddia edilmiştir. Sinema literatüründe alan derinliği kavramı ayrı bir tartışma konusu oluşturmuş olsa da, şaşırtıcı bir şekilde fotoğraf üzerine tartışmalarda konunun teknik boyutunun dışına çıkan ve kavramı felsefi ve estetik boyutuyla inceleyen çalışmalar mevcut değildir. Burada, öncelikle alan derinliği kavramının sinema literatüründeki estetik içerimleri tartışılmış, daha sonra fotoğrafın belirtisellik kavramıyla ilişkili olarak kavramın bahsedilen iki farklı temsil alanı açısından analizi yapılmıştır.

Rudolf Arnheim (1957:12) sinemaya dair ontolojik düşüncenin çok temel sorunlarından birisini gündeme getirmiş ve filmin basitçe iki boyutlu bir yüzey olmadığını belirtmiştir: "Film ne tamamen iki boyutlu ne de tamamen üç boyutlu bir temelde işler; aslında bu ikisi arasında bir yerdedir. Film görüntüleri aynı anda hem düz hem de cismanidir." 1 Bu noktada Arnheim filmle gerçeklik arasındaki algısal farklılıkları alan derinliğinin azaltıldığı bir boyutta, yani iki boyutluluk ile üç boyutluluk arasında kalan bir düzlemde tanımlamaktadır. Arnheim sinemayı sanatsal bir form olarak tanımlamaya çalışırken, film medyumunun gerçekliğin mekanik olarak yeniden üretimi veya kopyası olmadığını, sinemanın asıl işlevinin imgeleri anlamlı formlara çevirmek olduğunu iddia eder. Medyumun kendine has bir takım özelliklerini ve uygulama yollarını listeleyerek (Arnheim, 1957: 127-132), gerçeğin yeniden üretimi olan sinemayı bu nitelikler bakımından sanatsal sinemadan ayırır ve böylece özcü (essentialist) bir sanatsal sinema kuramı geliştirir. Ona göre sanat, ancak temsil koşullarının nesnenin şekillendirilmesinde rol oynadığı, yani mekanik yeniden üretimin sona erdiği durumda imkânlıdır (Arnheim, 1957: 57).² Arnheim'ın kavramsallaştırmasında filmin, resim sanatının aksine düz, mekanik yeniden üretimi temel alan imgeler üretmemesi ve kendine has bir derinlik temsili kurması bir anlamda medyumun sanat olabilmesinin ön koşullarından birisidir. Arnheim'ın filmi sanat olarak tanımlamasının temelinde 'esas olarak film nedir' gibi bir ontolojik sorunun yatmadığı düşünülebilir. Arnheim (1957: 213), filmin diğer sanatlar düzeyine yükselmesi için fotoğrafın yeniden üretim nosyonundan ve realizminden sıyrılması gerektiğini söylerken sanatsal film (ki ona göre siyah beyaz ve sessiz olması bir ön koşuldur) ve gerçekliğe yaklaşmaya çalışan film (renk ve ses Arnheim'a göre bu etkiyi sağlayan unsurlardır) arasındaki ayrım üzerinden tartışmasını sürdürmektedir. 3 Dolayısıyla, Arnheim'a göre sinemanın sanat olarak ortaya çıkışı, film ve gerçeklik arasındaki ayrım üzerinden şekillenmektedir. Ancak bu ayrım Arnheim'da daha çok fenomenolojik bir ayrım olarak belirir. Arnheim (1957: 15-16) 'kısmi yanılsama' kavramıyla izleyicinin sinema perdesindeki imgeyi gerçek dünyadaki gerçeklik olarak gördüğünü ancak bunun sadece algısal bir yanılsama olduğunu belirtir. Daha da ötesi izleyicinin nesneleri ve olayları hem gerçek (yaşayan) hem de imgesel olarak, yani hem gerçek nesneler hem de perde üzerindeki ışık örüntüleri olarak görebilme olanağı filmin sanat olabilmesini sağlar (Arnheim, 1957: 29).

Alan derinliğinin sinemanın neredeyse ayırıcı bir özelliği olarak tanımlandığı diğer bir kuramsal düzlemi ise André Bazin'de görmekteyiz. Bazin (1967a:35), alan derinliğini filtre kullanımı ya da ışıklandırma gibi teknik bir olanak olarak görmekten ziyade onu "sinema dili tarihinde atılan diyalektik bir adım” biçiminde tanımlamaktadır. Montaj, sinematik imgedeki ifade belirsizliğini söküp atmayı ve anlam birliğine ulaşmayı amaçlamaktayken, odak ve alan derinliği sinematik imgeye ifade belirsizliğini yeniden kazandırmaktadır (Bazin, 1967a: 36). Bazin, Arnheim'ın anlayışına karşıt bir şekilde, alan derinliği kavramını imgelerin görünümüyle ilgili bir düzleme değil, ontolojik bir düzleme yerleştirmektedir. Ancak Arnheim'da alan derinliği gerçekliğin mekanik yeniden üretiminden ziyade imgelerin anlamlı formlara dönüştürülmesinin temel bir aracı olarak gerçeklikle karşıt bir 
sanat kavrayışının temelinde dururken, Bazin'de teknik bir olanak olarak değil yeni bir dilin kurucu ögesi olarak, metafizik bir düzlemde gerçekçi bir estetiğin temel unsuru olarak belirmektedir. Ancak Bazin'in alan derinliği kavramını diyalektik bir adım ve devrimci bir araç olarak görmesinin temelinde genelleştirici bir ifade olduğunu söylemek yanıltıcı olur. Bazin (1967a: 33-35; 1967b: $35,38)$, Orson Welles ve William Wyler gibi yönetmenlerin derin odakla sağlanan geniş alan derinliği kullanımlarını sinemanın nesnel gerçekliğe yakınlaştığı bir estetik form ve devrimci bir adım olarak görmektedir. Bazin, bu yönetmenlerin derin odağa dayanan geniş alan derinliği kullanımlarının gerçek hayattaki fiziksel mekân ve zaman deneyimlerine dayandığını iddia ederek, bu estetik formu, imgeyi izleyicinin kendisinin deneyimleyeceği bir yüzey olarak değil algıyı belirli bir anlatı dahilinde yönlendiren bir yüzey olarak inşa eden geleneksel montajın karşısına koymaktadır. ${ }^{4}$

Özellikle Bazin'de ve sinemanın gerçekçi estetiği temelinde kurgulanan diğer anlatılarda hem fotoğrafın hem de sinemanın temsili problematik hale getiren bir aşkınsallığın araçları olduğunu görmekteyiz. Bazin ve Arnheim her ne kadar sinema ve gerçeklik arasındaki ilişkiye çok farklı noktalardan yaklaşsalar da, iki karşıt unsur, yani Arnheim'da kısmi yanılsama kavramı, Bazin'de ise sinemanın temel amacı olarak görülen estetik ve ontolojik gerçeklik nosyonunun ikisi de, filmin sanat olarak tanımının temelinde yer almaktadırlar. Ancak bu iki düşünürün de filmin sanat olarak kavramsallaştırmalarının temelinde fotoğrafın gerçeklikle ilişkisi problematiğinin yattığı görülebilir. Bu makalede, temel sorunun fotoğrafın (ya da duyarkatın) belirtisellik (indexicality) niteliğiyle birlikte gelen 'aracısızlık' kavramında ve sinematik/fotografik medyum ile 'doğal görmeyi' sunduğuna inanılan Rönesans perspektifi ve diğer temsil biçimleri arasındaki ilişkide düğümlendiği iddia edilecektir. Her ne kadar fotoğrafın doğrusal perspektif ile şekillenen görme rejimleri ile doğrudan ilişkisi literatürde yaygın bir tartışma konusu ise de, alan derinliği ile fotoğrafın belirtisellik özelliğinin ilişkisinin bu bağlamda tartışılmadığını görüyoruz. Bu tür bir tartışma çok daha kapsamlı bir analizi içerse de bu kısıtlı bağlamda soruna ilişkin kuramsal temellerin ve getirdiği problematiklerin tartışılması hedeflenmektedir.

\section{Fotoğrafın Belirtisellik Niteliği}

Klasik tartışmalarda, fotoğrafı resim gibi diğer görsel medyumlardan ayıran ve ona özgü olan gerçekçiliğin, temelde fotografik gönderge (referent) ile imge arasında kurulan kendine has bir ilişki üzerinden tanımlandığını görmekteyiz. Bu gerçekçilik iddiası, fotoğraflanan nesnenin fotografik imge halini alan yüzey üzerine kazındığı ve fotoğrafın belirti niteliğine büründüğü varsayımı ile şekillenmektedir. Bu kavramsallaştırma esasında fotografik yüzeyi 'gerçeğin’ bir kalıntısı, izi ya da baskısı olarak görmektedir. Örneğin Susan Sontag'a (1990: 154) göre fotoğraf yalnızca resim gibi gerçeğin yorumu olan bir imge değil, bir ayak izi ya da ölüm maskesi gibi gerçeğin damgasını taşıyan bir izdir. Bazin (1967c: 14) daha da ileri giderek fotografik imgenin nesnenin kendisi olduğunu iddia eder. Bazin böylece fotoğrafı nesnenin mevcudiyetinin bir 'uzantısı' olarak tanımlar ve fotoğraf için fazlaca kullanılan 'gerçekliğin aynası' eğretilemesinin ötesine geçer. Birçok farklı kuramcı, fotoğrafı, belirtisellik niteliğini vurgulayacak şekilde bir 'iz' ya da 'kalıntı' olarak kavramsallaştırmıştır. Arnheim'ın (1974: 155) daha önce alıntıladığımız iddiasının yanı sıra, Rosalind Krauss (1985: 203) fotoğrafı tanımlarken benzer eğretilemeler kullanarak fotoğrafı kumdaki ayak izlerine ya da tozlu bir zemin üzerine çizilmiş işaretlere benzetir. Bu kavrayışın çağdaş temsilcilerinden Carol Armstrong, fotoğrafın ilk önce belirtisellik özelliği ile tanımlanabileceğini, gönderme yaptığı şeylerin optik ve kimyasal bir sonucu olduğunu belirtir; fotoğraf, "anlaşılabilirlik kodları tarafından aktarılmadan önce doğayla olan iliş̧isine dayanmaktadır" (Armstrong, 1998: 2).

Fotoğrafın belirtisellik özelliği, özellikle ilk yaygınlaşmaya başladığı dönemlerde, fotoğrafın gizemli ve sihirli bir süreç olduğu yanılsamasının temelinde yatan unsurdur. Aslında fotoğrafın sihir ve büyü ile ilişkilendirilmesi sadece ilk izleyicilerle sınırlı bir olgu değildir. Antropologların genel bir gözlemi olarak 'ilkel' insanlar kame- 
ranın onlardan bir parçayı alacakları inanışındadırlar. Félix Nadar (1978: 9), Balzac'ın fotoğraflanmaya karşı tedirginliğin de ötesinde benzer bir korkusu olduğunu belirtmiştir. Bu tekinsiz duygunun temelinde fotoğrafın belirtisellik özelliğinin yattığını söyleyebiliriz. Nesnenin fotografik yüzey üzerine kazınması ve zamanı aşan bir sürekli mevcudiyet kazanması nesnenin bir parçasının 'orada' kaldığı düşüncesine yol açmış olabilir.5 Bu özellik bazen aşırı coşkulu ve dayanaksız iddiaların da temelini oluşturmaktadır. Buna dair en dikkat çekici örnek olarak W. Henry Fox Talbot'ın iddiası verilebilir: Fotoğrafta "resmi yaratan sanatçı değildir, resim kendi kendisini yaratmaktadır" (Bucklan, 1980: 43). 6 Daha da ötesi, fotoğraf 1839'da ilk kez kamuoyuna tanıtıldığında onu 'sihirli' kılan şey, diğer imge formlarının nesneleri tasvir etme kabiliyetini (yani temsil gücünü) aşan bir teknik araç olma özelliği değildir. Fark edilmesi zor, en ince detayları kopyalayan bir gerçekçi resim bile yanlış pozlanmış, net olmayan siyah beyaz bir fotoğraf kadar otantisite yayamaz. Dolayısıyla fotografik gerçekçilik bu bağlamda fotoğraflanan nesnenin tutarlı ve mükemmel temsiline değil diğer imge formlarının hiçbir zaman ulaşamayacağı bir şeye yani belirtisellik özelliğine dayanmaktadır. Başka bir deyişle fotoğraf otantik ve hakiki olmak için 'gerçekçi' (realistic) olmak zorunda değildir. Nesnenin kendisinin izini taşıdığı için bir yapıntı değil doğal bir olgu olarak tahayyül edilmektedir. Ancak, muhtemelen fotoğraf üzerine klasik tartışmalarda hiçbir yazar gönderge ile fotografik imge arasındaki özel ilişkiyi ve bu ilişkinin temsile ilişkin ortaya çıkardığı problematiği Roland Barthes kadar yetkin bir biçimde dile getirememiştir. Barthes (1982: 99), fotoğrafı gönderge ile ilişkisinde şöyle tanımlar: "Fotoğraf, tam anlamıyla göndergenin fışkırmasıdır ... bir tür göbek bağı fotoğraflanan şeyi benim bakışıma bağlar." Barthes (1982: 87) ekler: Her fotoğraf bir “mevcudiyet belgesidir.” Barthes'a (1982: 87) göre fotoğrafı ilk kez seyreden kişiler bu "mutant" imgeleri "ne imge ne de gerçeklik olarak", fakat "dokunulamayacak bir gerçeklik olarak” algılamış olmalıdır.7 Dikkat edilirse Barthes fotoğrafı gerçekliğin bir temsili olarak görmekten ziyade kendi içinde bir gerçeklik kipi ya da yüzeyi olarak görmektedir. Diğer bir bağlamda Barthes (1977: 17-18) fotografik mesajı "kodsuz bir mesaj" olarak görecek ve fotoğrafın gerçekliğin mekanik bir analogu olarak kendi varlık kipini yok eden ve temelde kendinden başka bir şey belirtmeyen mesajı içeren bir medyum olduğunu söyleyecektir. Dolayısıyla Barthes'ın anlatısında fotoğraflar basit bir temsil ilişkisinin ötesine geçmekte, nesnelerinin izleri ile işlendikçe temsil için neredeyse birer kara delik olmaktadırlar. Görsel medyumlar içinde yalnızca fotoğraf gösterdiği nesneyi kendisinden daha gerçek, görünür ve önemli kılmaktadır. Temsil süreci içinde medyum, içerikten daha önceliklidir; aslında bu yüzden temsil sunum (presentation) değil yeniden sunum (representation) olarak adlandırılmaktadır. Dolayısıyla temsil medyumun baskın mevcudiyetini ve Platonik gerçeklik (ya da hakikat) kavramını göstermektedir.

Temsil problematiğinin Barthes’ta daha da incelikli hale geldiği bölüm Barthes'ın (1982: 67-73) vefat etmiş annesini beş yaşında gösteren 'Kış Bahçesi' fotoğrafı üzerine duygularını ifade ettiği pasajdır. Barthes annesinin yüzünün hakikatini ona hatırlatacak bir fotoğraf peşindeyken, fotoğrafların genellikle nesnesi ile benzeşim aracılığıyla ilişki kurduğunu ve annesinin 'hakikatini' değil 'kimliğini' yansıttığını fark eder. Ancak annesini henüz 5 yaşında bir kış bahçesinde gösteren fotoğrafla karşılaştığında aradığını bulduğunu anlar. Barthes (1982: 71) 'Kış Bahçesi' fotoğrafının doğrudan öze ilişkin olduğunu ve bu fotoğrafın "biricik varlığın olanaksız bilimine" ulaştığını belirtir. Barthes her ne kadar Charles Peirce'ın ikonla belirti arasında kurduğu ikiliği izliyor gibi görünse de, ${ }^{8}$ doğrudan fotoğraf üzerine yazdığı bu metinde fotoğrafı bir belirti ya da 'ikonik belirti' olarak tanımlamanın ötesine geçer. Fotoğraf bir anlamda varlığın kendi mevcudiyetini ya da hakikatini fotoğrafın belirtiselliği aracılığıyla açtığı bir yüzeydir.

Bu noktada, Barthes'ın anlatısında ve fotoğrafın belirtisellik özelliğini fotoğrafı diğer medyumlardan ayırt eden bir özellik olarak gören diğer klasik tartışmalarda, medyumun temsil kavramının anlamını tehdit edecek düzeyde bir saydamlığa erişmekte olduğu iddia edilecektir. ${ }^{9}$ 
Bu saydamlık iddiası ve fotoğrafın belirtisellik özelliği benzerlik nosyonu ile ya da fenomenolojik bir düzlemde kavranamaz. Belirtisellik ve saydamlık, fotoğrafın toplumsal uzlaşımlar ve kodlardan büyük ölçüde bağımsız olan ve temsil alanını problematize eden ontolojik özelliğine yaslanmakta, fotoğrafı belirli bir görme biçimini inşa eden bir aygıt olarak değil aracısız/doğrudan bir olgu olarak tasavvur eden kavramlardır. Bazin ve Arnheim'da sinemada gerçekçi bir estetiğin kurulmasına temel teşkil eden 'doğrudan' fotoğraf kavramı ile Barthes'ın fotoğrafın doğrudanlığını ya da aracısızlığını vurgulayan 'varlıksal' fotoğraf kavramı bu tür bir nötr aygıt nosyonuna dayanmaktadırlar.

\section{Modern Görme Rejimi ve Camera Obscura}

Sinema tartışmalarında çok temel bir okul olan aygıt kuramının bazı gözlemleri, fotoğrafın şeffaflı̆̆ı ve belirtiselliği sorununa yeni açılımlar getirebilir. ${ }^{10}$ Aygıt kuramının temel iddiası fotoğraf ve sinema dahil tüm aygıtların bize doğal veya doğrudan/aracısız göründüğü, aslında bu aygitların ideolojik oldukları ve toplumsal oluşumlar ve kültürel pratikler içinde düşüncemizi, algı biçimlerimizi biçimlendirdiği iddiasıdır. Örneğin Jean-Louis Comolli (1986: 422-423), Bazin gibi film kuramcılarını idealist kampa dahil ederken, bu kuramcıların alan derinliği kavramını oluşturan teknik araçları doğal ve nötr nosyonlar gibi algıladıklarını halbuki tekniğin ideolojiden bağımsız olmadığını belirtir. Genel olarak aygıt kuramının analizine paralel olarak, Comolli yakın çekim (close-up; referans verilen metinde closeup) ve alan derinliği kavramıyla ilişkili olan derin odak nosyonlarının temelde teknik belirlenimlerle değil ekonomik ve ideolojik belirlenimlerle inşa edildiğini iddia etmektedir. Comolli'ye göre bu ekonomik ve ideolojik belirlenimlerin analizi, derin odak ve buna bağlı olarak alan derinliği bağlamında sadece sinemaya özgü olmayan kodların (resimsel, pictorial, dramatik ve fotografik kodlar gibi) sinemada anlam üretimi süreçlerinde nasıl inşa edildiğini ve biçimlendirildiğini anlamamızı sağlayacaktır. Comolli'nin (1986: 431) bu noktada Bazin'e ve idealist olarak tanımladığı diğer kuramcılara temel itirazı, film metninin ve dilinin gelişimini yeni araçların ge- liştirilmesi ile paralel bir teknik ilerleme olarak görmeleri ve teknik süreçleri tarihten, kodlardan ve ideolojilerden bağımsız görme eğiliminde olmalarıdır. 'Teknik ideolojisi' olarak adlandırdığı bu kuramlar tekniğe ait pratikleri anlamlandırma sistemlerinden ayırmakta ve bu pratikleri film metninde anlamı oluşturan nedenler olarak açıklamaktadırlar.

Comolli, tartışmasını tarihsel bazı örneklerle sürdürür. Jean Mitry'ye eleştirisinde onun bir gözleminden hareketle aygıt kavramının ideoloji ve anlamlandırma sistemleri ile ilişkisini ortaya çıkarmaya çalışır. Jean Mitry'nin (2000: 59) belirttiği gibi 1915'ten önce çekilmiş filmlerde derin odak (geniş alan derinliği) kullanımı sadece ışığın yeterli olduğu dış mekan çekimlerinde görülmekte ve bu filmlerde genellikle $35 \mathrm{~mm}$ ve $50 \mathrm{~mm}$ objektifler kullanılmaktadır. ${ }^{11}$ Bu objektifler geniş açı objektifler olmadığı için geniş alan derinliği sadece yüksek (göreli olarak kapalı) diyafram değerlerinde elde edilmekte ve bu da ancak ışı̆ıın yeterli olduğu dış mekân çekimlerinde mümkün olabilmektedir. Comolli (1986: 433) bu noktada temel bir soru sorar: Sinemanın ilk yirmi yılında neden sadece bu odak uzunluğuna sahip olan objektifler kullanılmaktadır? Comolli bu odak uzunluğundaki objektiflerin 'normal görüşe' tekabül eden mekânsal ilişkileri yeniden inşa ettiği ve bu yolla gerçeklik etkisi yarattığı için kullanıldığını söyler. Dolayısıyla bu objektifler benzerlik ve gerçekçilik kodları ile belirlenmişlerdir. Comolli benzer bir tartışmayı geniş alan derinliği ve perspektif arasında kurduğu ilişkide de yineler. Filmlerde karakterlerin perde üzerinde 'dikey' hareketinin sağlanması (yapay perspektif), ancak yeterli ışık, çok katmanlı düzlemler ve dolayısıyla geniş alan derinliği ile mümkün olmaktadır. Comolli'ye (1986: 434) göre bu yapay perspektif ve onu mümkün kılan derin odak (geniş alan derinliği) klasik Batı temsil formlarının resimsel ve dramatik kodlarının unsurlarıdırlar. Dolayısıyla Comolli daha önce teknik ideolojisi olarak adlandırdığı ideolojinin sandığının aksine hareket ve derinliğin inşasının kameranın bir sonucu değil, tam tersine bir aygıt olarak kameranın kendisinin bu inşa sürecinin bir sonucu olduğunu iddia etmektedir. Her ne kadar sinema tarihçileri alan 
derinliği kullanımının sinemada teknolojik ilerlemelerle birlikte geliştiğini iddia etseler de, Comolli tarihte daha ilk filmlerden itibaren sinematik imgenin 'doğal olarak' derin odaklı bir imge olduğunu belirtmektedir. Comolli, genel olarak ifade edilirse, sinemanın kendisini önceleyen temsil formlarının dayandığı 'normal görüş' ve Rönesans perspektifini yeniden üretmeye çalıştığını söylemektedir. Teknik ilerlemeler 'idealist' film kuramcılarınca nötr olarak görülmekte ve aygıtın kendisinin bir toplumsal inşa sürecinin ürünü olduğunu göz ardı etmektedirler.

Jean-Louis Comolli'nin tartışmasında temel noktalardan birisi ‘normal görme' kavramının kendisinin de bir toplumsal inşa olduğu imasıdır. Normal görme kavramı Rönesans'ta üç boyutlu mekânın iki boyutlu tuval üzerinde temsil edilebilmesini sağlayan doğrusal perspektif kavramı ile şekillenen bir olgudur. Rönesans'ın temel kaygisı tasvir edilen nesneden ziyade perspektif yanılsaması yaratmak ve nesneden ziyade mekâna önem yüklemektir (Jay, 1994: 51-52). 1927'de Erwin Panofsky (2013: 11), perspektifin mekânı kurgulama biçimini ve bunun görme kavramıyla ilişkisini şu şekilde ifade etmiştir:

“Tamamen rasyonel, başka bir deyişle sonsuz, sabit ve homojen bir mekân konstrüksiyonunu garantiye alabilmek için, 'merkezi perspektif' aslında dile getirilmeyen son derece önemli iki temel öncülden hareket eder: Bunlardan birincisi, hareketsiz tek bir gözle bakıyor olduğumuz öncülüdür; diğeri ise, görme piramidini bölen düzlemsel arakesitin, bizim optik imgemize muadil bir reprodüksiyon olduğudur. Aslında bu iki öncül de, gerçekliğin ... epey cüretkâr soyutlamalarıdır."

Panofsky, Rönesans'ın bu matematiksel mekânının psikofizyolojik mekânla tamamen zıt olduğunu ve algılanan mekânın sonsuzluğu tanıyamayacağını ifade etmektedir. Belki de en önemli tespit olarak, bu geometrik mekân anlayışındaki varlık kavramının tözsel olmadığını, varlı̆̆ın perspektif inşasında konumu gösterilen işlevsel bir varlık haline geldiğini iddia eder. Bu tartışmanın bağlamı açısından kritik önemde olan diğer bir nokta, pers- pektifin inşa ettiği mekânın görüş nosyonunu kurgulama biçimine ilişkindir: Mekânın doğrudan deneyimine yabancı olan homojenlik ve sonsuzluk kavramları perspektif kavramında mekânın temsil edilebilmesi için mekâna içkin unsurlar halini almaktadır. "Dolayısıyla perspektif, mekânın kısımlarının ve içeriklerinin tümünü” sürekli nicelik halinde "iç içe geçirebilmek için, ön ve arka, sağ ve sol, cisim ve ara maddesi ('boş’ mekân) arasındaki farkı” yadsımaktadır (Panofsky, 2013: 13). Daha da ötesi, doğrusal (merkezi) perspektif kavramı "sabit tek bir gözle değil, sürekli hareket eden iki gözle gördüğümüzü, böylece 'görüş alanımızın' küremsi bir şekil aldığı olgusunu gözardı etmektedir" (Panofsky, 2013: 13). Görmenin ve mekânın bu temsili, Panofsky’ye göre, psikolojik 'optik imge' ile mekanik 'retina imgesi' arasındaki farkın yadsınması üzerine kurulmuştur.

Dolayısıyla, modernitenin baskın görme rejimini ifade eden Rönesans perspektifi ya da Martin Jay'in (1988: 4) deyimiyle 'Kartezyen perspektifçilik' niceliğe dayanan ve nesnelerin iki boyut üzerinde konumlandırılabileceği bir matematiksel mekâna ve tekgözlülüğe (monocularity) dayanmaktadır. ${ }^{12}$ Jay'in (1988: 5-6) belirttiği gibi doğrusal perspektifin asıl anlamı, geç ortaçağın büyülendiği ışığın metafizik içerimlerinden (ki burada ışık algılanan bir ışıktan, lumen, ziyade ilahi bir nur, lux, kavramını belirtmektedir) doğmaktadır: "Doğrusal perspektif optikteki matematiksel düzenlilikler ve Tanrı'nın iradesi arasındaki uyumu sembolize etmektedir". Ve dahası bu denklemin dinsel anlamları çözündükten sonra bile sözde nesnel optik düzenin çağrıştırdığı anlamlar gücünü sürdürmüştür. Rönesans perspektifini ve ışı̆̆ın bu metafizik içerimlerini en çok güçlendiren olgulardan birisi de camera obscura olgusudur. Işığın küçük bir delikten kapalı ve karanlık bir hazneye geçişiyle haznenin duvarında ters bir imgenin oluşması olgusu, genellikle bir optik aygıt olarak adlandırılsa da çoğu kez doğanın kendi kendisinin imgesini oluşturması şeklinde bir aracısızlık ve doğrudanlıkla özdeşleştirilmiştir. Bu doğrudanlık iddiasıyla ilişkili bir biçimde, olgunun insanın görme işleviyle benzer olup olmadığı da antik çağdan beri tartışılan bir konudur. Daha da ötesi, ol- 
gunun insanın şeyleri bilme sürecinin eğretilemesi olarak kullanıldığını görmekteyiz. Descartes'a göre camera obscura, gözlemcinin dünyayı zihninin algısıyla ve kendine özgü biçimde bilmesinin bir gösterimidir (Crary, 1988: 32). Burada içsel mekânda benliğin güvenli konumlanışı ve özne-nesne arasındaki mesafe, dış dünyayı bilebilmek için bir ön koşul olarak tariflenmektedir.

Camera obscura'nın ve 'Kartezyen perspektifçiliğin' tekgözlü modeline tekrar dönelim. Burada kuşkusuz insan görüşü ile karşıt bir biçimde konumu belirli ve tek bir noktadan farklı derinliklerdeki nesneleri bir düzlem dahilinde ve perspektif ilkeleri içinde 'aynı anda' gören bir 'tek göz' eğretilemesini kullanabiliriz. Martin Jay (1988: 7), tekgözlü modeli şu şekilde tariflemektedir:

“[Gören göz] ikigözlü görmenin aksine tekildi. Önündeki manzaraya bir gözetleme deliğinden bakan bir yalnız göz biç̧iminde tasavvur edilmişti. Dahası, bu tür bir göz durağan, gözünü açıp kapamayan, dinamik değil sabit olarak, daha sonraki bilim insanlarının 'sekmeli' sıçrayışlar olarak adlandıracağı, bir odak noktasından diğerine geçen bir hareket içinde anlaşılmaktaydı. Norman Bryson'un [1983] deyimiyle, göz, Göz Atma [Glance] mantığı yerine Bakış [Gaze] mantığını izlemekteydi. Dolayısıyla, ebedileştirilmiş, bir 'bakış açısına' indirgenmiş ve ruhani bir görme eylemi üretmekteydi."

Modernitenin, bilgi ya da hakikatin yorumlanmasını görme duyusuna dayandıran ve onu duyuların en ayrıcalıklısı haline getiren gözmerkezci (ocularcentric) paradigmasındaki baskın modelin tekgözlülük olduğu söylenebilir. ${ }^{13}$ Kartezyen modelin bilen özne ile bilinen nesne dünyası arasında kurguladığı mesafe bir anlamda optik modelin ve görme rejiminin kendisini de inşa etmiştir. Kartezyen modele dayanan birçok görme teknolojisi ile somutlaşan nesneleştiren bakış, Descartes'ın gözün fizyolojisi ile mekanik objektifi birleştirmesi nosyonuna dayanmaktadır. ${ }^{14}$

\section{Sonuç: Alan Derinliği ve Belirtisellik}

Kuşkusuz fotoğrafın icadı modern görme rejiminin gelişimi için bir dönüm noktası oluşturmuş, fotoğraf toplumsal alanda yüklendiği farklı işlevlerle modernitenin gözmerkezcilik paradigmasını yaygınlaştırmıştır. Kartezyen özne-nesne ikiliğinin büründüğü farklı toplumsal formların yaygınlaşması ve içselleştirilmesinde fotoğraf gibi görme teknolojilerinin bilgi, iktidar ve beden arasındaki ilişkileri yeniden inşa etmesinin rolü büyüktür (Foucault, 1995). Ancak, tartışmanın başından beri ima ettiğim bir noktadan, fotoğraf üzerine klasik tartışmalarda bazen açıkça (Barthes örneğinde) bazen de üstü kapalı bir şekilde (Bazin örneğinde) beliren bir sınırlandırmadan, bahsetmek yerinde olur. Fotoğrafın 'aslında' ne olduğu Barthes için toplumsal kodlardan ve uzlaşımlardan bağımsız olarak incelenmesi gereken bir olguydu. Kuşkusuz Barthes bu tür bir kavramsallaştırmanın sorunlarının farkındaydı. 'Çağdaş mitlerin' oluşumunda görsel formların detaylı bir göstergebilimsel analizini yapan Barthes (1972) için fotoğrafın bu oluşumdaki merkezi rolü ve daha genel olarak modernitenin görme rejiminin yaygınlaşmasındaki oluşturucu payı yadsınamaz. Ancak hem Barthes'ta hem de gerçekçi estetik peşindeki Bazin'de fotoğrafı diğer medyumlardan ayıran özelliğin, tutarlı ve gerçeğe yakın temsil iddiasına yaslanan ve temelinde benzerlik bulunan perspektif anlayışından tamamen farklı bir alanda kurulduğunu görmekteyiz. Kuşkusuz Kartezyen perspektifçilik ve camera obscura'nın temelinde yer aldığı görme rejimi, bir yandan evrensel bir gözün nesneleştirdiği ve özneden tamamen kopardığı bir epistemolojik nesne, bir yandan da tekgözlü model ile 'normal görmeyi' birleştiren, fenomenolojik bir mütekabiliyet ilişkisi peşindeydi. Daha önce de belirtildiği gibi fotoğrafı ilk izleyicileri için büyülü ve otantik yapan unsur 'mekanik olan objektifin tam olarak insan gözünün gördüğünü göstermesi' değildir; öyle olsaydı fotoğraf büyüsünü yüzyıllardır bilinen bir olgu olan camera obscura ile paylaşırdı. Fotoğrafın özgünlüğüne işaret eden anlatılar, mekanik objektifin ‘neyi gördüğü' ile ilgisi olmayan, yani meseleyi fenomenolojik bir düzleme indirgemeyen, fotoğrafı ontolojik bir temelde 'belirti' olarak tanımlayan 
bir konumdan yola çıkmaktadırlar. Eğer fotoğrafın belirti olmasının ön koşulu olarak aracısızlık ve doğrudanlığı koyacaksak (ki bu eski bir eğretilemeyi kullanırsak fotoğrafı 'gerçekliğin aynası' olarak görme anlamına gelecektir ve burada tanımlanmaya çalışılan konumla tamamen terstir) kuşkusuz fotoğrafın modernitenin görme rejimini yeniden üreten bir aygıt olarak belirti özelliği temelsiz hale gelecektir.

Ancak, bu kavramsallaştırma da sorunsuz bir kavramsallaştırma değildir. Paradoksal gibi görünse de, fotoğrafın bir iz olarak tahayyülü ya da onu diğer görsel medyumların dışına biricik bir yere yerleştiren 'bir belirti olarak fotoğraf' kavramı, camera obscura olgusu üzerinde temellenmektedir. Kuramsal olarak camera obscura'da alan derinliği sonsuzdur; yani camera obscura, her ne kadar tekgözlü bir model olsa da, kavramsal düzeyde sonsuz sayıdaki nesnenin her birini ayrı ayrı, derinlik farkı olmaksızın düz bir yüzeye aktaran ve hepsini tek tek 'gören' sonsuz sayıda göz nosyonu ile işlemektedir. Her ne kadar fotoğrafta sonsuz alan derinliği kavramı mümkün değilse de, fotoğrafın belirtisellik özelliği yine sonsuz sayıdaki nesnenin her birinin izinin netlik farkı oluşmaksızın aynı formda yüzeye 'kazındı̆̆ı' varsayımına dayanmaktadır. Bazin'de alan derinliğinin belirli kullanımlarının sinemanın realist bir estetik temelde kurulması yönündeki merkezi önemi bu noktada açıklık kazanmaktadır. Şimdi hayli sığ bir alan derinliği içinde fotoğrafın nesneleriyle ve mekânla kurduğu ilişkiyi düşünelim. Kuşkusuz bu tür bir fotoğrafta nispeten odak alanı içerisinde bulunan nesneler aracılığıyla dramatizasyon oluştuğunu ancak yine aynı fotoğrafın mekândaki derinliği sığ alan derinliği kullanarak temsil etmeye çalıştığını göreceğiz (bu, sinemada geniş bir alan derinliğinde nesnelerin hareketiyle sağlanabilmektedir). Yani fotoğrafın iki boyutluluğa dayanan belirtisellik özelliğinin, mekânsal derinlik ve üç boyutluluğun temsil edildiği formlar ile paradoksal bir ilişki içinde olduğunu söyleyebiliriz. Başka bir deyişle, fotoğraf mekânsal derinliği temsil etmeye başladığı anda ikigözlü modeli veya üç boyutluluğu yeniden üretmeye çalışmakta, mekânı 'düzlediği' anda ise ona kendine özgü realizmini veren belir- tisellik özelliğini kazanmaktadır. Dolayısıyla, sadece nesne üzerinden temellenen bir realizmden bahsetmezsek genel olarak fotografik realizmin iki farklı formu, nesnesi ile kurduğu ilişkide tekgözlü bir modele, mekânla kurduğu ilişkide ise ikigözlü bir modele dayanmaktadır.

Fotoğraf mekânsal derinlik temsiline yöneldiği formda, yani alan derinliğinin daraldığı durumda, bir anlatıya, dramatik bir forma dönüşmektedir. Bu durumda mekânın 'gerçekçi' temsili, fotografik nesnenin seçmeci bir şekilde gösterilmesi ve artık fotoğrafın o nesne dışındaki şeylerin 'yok olduğu' kavramsal bir düzleme indirgenmesi pahasına olmaktadır. Halbuki camera obscura kuramsal olarak nesneleri yok etmez, mekânı derinlik kavramı açısından değil nesnelerin birbirlerine göre konumları ve büyüklükleri ile temsil eder. Doğrusal perspektifin görmeye ilişkin ortaya koyduğu model ile kuramsal olarak alan derinliğinin sonsuz olduğunun varsayıldığı fotografik yüzeydeki model birbirleriyle özdeştir. Burada problematik olan nokta, fotoğrafla resmi birbirinden ayıran belirtisellik özelliğinin bu düzlemde pratik olarak mümkün olmamasıdır. Yani hiçbir optik aygıt (camera obscura dahil) sonsuz küçüklükte bir diyaframa (veya ışığın geçtiği deliğe) ve dolayısıyla sonsuz alan derinliğine sahip olamaz. Ancak bu noktada yine daha önce belirttiğim fenomenolojik düzlemde tanımlanan bir belirtisellik kavramına tekrar dönmekteyiz. Kuşkusuz fotoğraf pozlanma biçimleri ve alan derinliği kullanımından bağımsız bir biçimde belirtisellik özelliğini gösteren bir medyumdur.

Aygıt kuramının fotoğrafın belirtisellik özelliği ve alan derinliği ile kurulan mekânın temsiline ilişkin içerimlerinin salt fenomenolojik açıklama tuzağına düşme tehlikesi vardır. Her ne kadar klasik tartışmalar da bahsedilen sorunlardan azade değilse de, aygıt kuramının bu bağlamda içerimleri, fotoğrafın 'gerçekliğin aynası' olduğu şeklindeki eğretilemeye karşılık gelen bir realizm iddiası ile şekillenmektedir. Bu iddia da büyük ölçüde Rönesans perspektifi ile şekillenen bir 'normal görme' nosyonunun mekanik objektif ile gerçekleştiği varsayımından kaynaklanmaktadır. Ancak belirtisellik nesnelerin herhangi bir görsel medyum aracılığıyla 'nasıl göründüğüne' değil, fotografik 
nesnenin medyum ile olan ilişkisine dayanan, yani medyumun 'aslında ne olduğu' sorusuna dayanmaktadır. Eğer belirtisellik fenomenolojik bir düzleme dayansaydı, fotoğraftan ayırt edilmeyecek 'realist' resimler, doğrudanlık ya da aracısızlık niteliğini kazanmış, yani basitçe 'normal görme' olarak tanımlanmış olurdu. Dolayısıyla fotoğrafın belirtisellik özelliği temelde görmeyi hangi formda inşa ettiğiyle değil, ışık aracılı̆̆ıyla nesnenin kendisinden bir parça taşıyor olmasıyla anlaşılabilir. Bu düzlemde fotoğrafın şeffaflı̆̆ı onun benzerlik üzerinden inşa edilen realizmine değil (veya 'gerçekliğin aynası' olma iddiasına değil), nesneyle kurduğu fiziksel bağ sayesinde edinilen bir özelliğe dayanmaktadır.

\section{Notlar}

1 Arnheim'ın kitabı ilk kez 1932 yılında 'Film als Kunst' başlığıyla yayınlanmıştır. Kitabın dilimizde çevirisi için bkz. Arnheim (2010). Metindeki tüm çeviriler, çeviri esere referans verilmediği durumlarda yazara aittir.

2 Burada Arnheim'ın örneklediği özcü sanat anlayışına getirilen eleştiriler üzerinde durmayacağım. Ancak Walter Benjamin'in $(1969 ; 2014)$ fotoğraf ve sinemanın sanat olarak tanımlanıp tanımlanamayacağı yönündeki tartışmaları tamamen beyhude tartışmalar olarak gördüğü çalışmaları anılmaya değerdir. Benjamin, bu medyumların sanatın doğasını tamamen değiştirdiğini iddia etmekteydi. Bu iddia Benjamin'de (2014: 8-9) en güzel ifadesini şu sözlerde bulur: “... fotoğrafçılık teorisyenleri neredeyse yüzyıl boyunca bu fetişist ve temelinde teknoloji karşıtı sanat anlayışına karşı durmaya çalışmışlarsa da, doğal olarak pek bir sonuç elde edememişlerdir. Bunun sebebi, fotoğrafçının yıkmak üzere yola çıktığı kürsünün önünde onay almasını sağlamaya çalışmalarıydı."

3 Arnheim'ın (1974: 155) şu gözlemi fotoğrafın realizmine ya da yeniden üretim nosyonunun fotoğraftaki oluşturucu önemine ilişkin görüşünü çok güzel yansıtmaktadır: Fotoğrafta "fiziksel nesneler kendi imgelerini ışığın optik ve kimyasal eylemiyle kendi kendilerine basmaktadırlar." Arnheim'ın (sanatsal) sinema ile fotoğraf arasında kurduğu bu karşıtlığın aksine Siegfried Kracauer (1997) sinemanın temel karakteristiklerinin fotoğrafla aynı olduğunu, asıl işlevinin gerçekliği yeniden üretmek olduğunu belirtir. Kracauer (1997: I) geleneksel sanatların hammaddesini sanatçının izlenimlerine uyacak şekilde değiştirdiğini, film veya fotoğrafta ise hammaddenin az ya da çok bozulmadan kaldığını belirtmiştir.

4 Ancak, şaşırtıcı bir şekilde, farklı odak kullanımları ile beliren çeşitli düzeylerdeki alan derinliği fotoğrafın temel bir unsuru olmasına karşın Bazin'de, her ne kadar açıkça olmasa da, sığ alan derinliğinin fotoğrafın temel özelliklerinden birisi olarak tanımlandığını görmekteyiz. Jean Renoir üzerine tartışmasında (Bazin belirtmese de sığ alan derinliği ile gelen) ar- kaplandaki odak dışı alanları hikaye anlatmaya yarayan montaj etkisi ve bunun da ötesinde fotoğraf dilinin bir unsuru olarak görmektedir (Bazin, 1967a: 33-34). Bu noktaya daha sonra fotoğraf bağlamında tekrar dönülecektir.

5 Fotoğrafın ilk izleyicilerinin tepkileri üzerine bilgi için bkz. Hannavy, 2008; Marien, 2006.

6 W. Henry Fox Talbot'ın 'Literary Gazette' editörüne 1839 yılında yazdığı mektuptan alıntı.

7 Bu noktada Barthes'ın anlatısını fotoğrafla ilk karşılaşmayı yeni bir teknolojik icatla karşılaşma anındaki tepkiye indirgeyen anlatılardan titizlikle ayırmak gerekir. Barthes fotoğrafın kendi içinde ne olduğunu (yani ontolojisini) anlamaya çalışmakta ve fotoğrafın toplumsal uzlaşımlar ve kodlarla örülü olan anlamlarından bağımsız özelliklerini ortaya koymaya çalışmaktadır.

8 Peirce'a (1998: 5-6) göre üç tür gösterge vardır. Bunlardan ilki temsil ettiği şeylerin fikrini onları taklit ederek ileten ikonlardır. İkinci tür gösterge temsil ettiği şeylere fiziksel bağlılığından dolayı onları gösteren belirtilerdir. Ve sonuncu olarak kullanımlar ve uzlaşımlar sonucunda temsil ettiği şeylerle bağ kuran göstergeler yani semboller bulunmaktadır. Peirce'a göre fotoğraflar, noktası noktasına doğaya karşılık gelmek zorunda olduğu için, herşeyden önce belirti türünde göstergeler olarak görülmek durumundadır.

9 Fotoğrafın saydamlığı (transparency) iddiaları özellikle Kendall Walton'ın (1984) çalışmasıyla anılmaktadır. Walton saydamlık tezinde fotoğrafın aynı ayna veya teleskop gibi görme alanımızı genişlettiğini, fotoğraf yoluyla geçmişteki şeyleri 'gerçekten gördüğümüzü' iddia etmekteydi. Bu mantıkla ayna nasıl görüş alanımızda olmayan şeyleri, teleskop ise çıplak gözle göremeyeceğimiz uzaklıktaki şeyleri görmemizi sağlıyorsa, fotoğraf da geçmişe yönelen bir görme sağlamaktaydı. Burada Walton'ın tezi tartışılmayacaktır. Ancak, her ne kadar fotoğrafın saydamlığı tezi yeni bir tez gibi görülse de aslında klasik tartışmalarda fotoğrafın saydamlığı tezinin tamamen ontolojik düzlemde ve üstü kapalı bir biçimde varolduğu iddia edilebilir.

10 Burada aygıt kuramının diğer tezleri tartışılmayacak, sadece kuramın alan derinliği kavramı üzerine yoğunlaşan temsilcisi Jean-Louis Comolli'nin temel görüşlerine değinilecektir. Comolli (1986: 430-438) alan derinliği kavramını metnin “"Primitive" Depth of Field' bölümünde tartışmaktadır. Burada özellikle bu bölüme odaklanılmaktadır. Aygıt kuramının psikanalitik film kuramı içinde eleştirel bir değerlendirmesi için bkz. Arslan (2009).

11 Jean-Louis Comolli'nin metni Fransızca'dan çevrilmiştir ve metin Mitry'nin Fransızca eserine referans vermektedir. Burada Mitry'nin gözlemi İngilizce çevirisinden alınmıştır.

12 Kuşkusuz literatürde modernitenin görme rejiminin sadece Rönesans perspektif anlayışı ve Kartezyen rasyonalizme yaslanan bir görme rejimi olup olmadığına dair tartışmalar vardır. Bazı düşünürler bu görme rejiminin 19. yüzyılda krize uğradığını (Crary, 1988: 31; daha geniş bir tartışma için bkz. Crary, 2010), diğer bazı düşünürler ise bu görme rejiminin her zaman baskın konumunu sürdüremediğini, dolayısıyla modernitenin görme biçimininden değil biçimlerinden bahsetmemiz gerektiğini öne sürerler (Rose, 1986: 232-233). Jay 
(1988: 12-17) ise özellikle Kuzey sanatında ve Barok dönemde bu baskın görme rejimlerinin tersine işleyen temsil biçimlerinden bahseder. Bu konu makalenin sınırlarını aşmaktadır. Özellikle doğrusal perspektifle gelen matematiksel mekân kavramı ve bu kavramın temellendiği tekgözlü modelin sinematik/fotoğrafik imgeye uygunluğu açısından tartışma Rönesans perspektifi ile sınırlandırılmıştır.

13 Bu en azından fotoğraf ve sinema için tartışılması güç bir yargıdır. Modernitenin gözmerkezci paradigması ve bu paradigmanın tek baskın paradigma sayılabileceği yönündeki tartışmalara getirilen eleştiriler için bkz. Levin (1993).

14 Descartes'ın optik üzerine açıklamalarından derlenen aydınlatıcı alıntılar için bkz. Descartes (2012).

\section{Kaynakça}

Armstrong, Carol (1998). Scenes in a Library: Reading the Photograph in the Book, 1843-1975, Cambridge, MA: MIT Press.

Arnheim, Rudolf (1957). Film as Art, Berkeley: University of California Press.

(1974). "On the Nature of Photography". Critical Inquiry 1(1): 149-161.

(2010). Sanat Olarak Sinema, çev. Rabia Ünal Tamdoğan, İstanbul: Hil Yayınları.

Arslan, Umut T. (2009). “Aynanın Sırları: Psikanalitik Film Kuramı.” Kültür ve Illetişim 12(1): 9-38.

Barthes, Roland (1972). Mythologies, çev. Annette Lavers, New York: Hill and Wang.

(1977). Image, Music, Text, London: Fontana Press.

(1982). Camera Lucida: Reflections on Photography, çev. Richard Howard, New York: Hill and Wang.

(2000). Camera Lucida: Fotoğraf Üzerine Düşünceler, çev. Reha Akçakaya, İstanbul: Altıkırkbeş Yayın.

(2014). Fotografinin Küçük Tarihi, çev. Barış Tanyeri, İstanbul: Altıkırkbeş Yayın.

Bazin, André (1967a). "The Evolution of the Language of Cinema”. What is Cinema?, c. 1, ed. Hugh Gray, Berkeley: University of California Press.

(1967b). "An Aesthetic of Reality". What is Cinema?, c. 2, ed. Hugh Gray, Berkeley: University of California Press.

(1967c). "The Ontology of the Photographic Image". What is Cinema?, c. 1, ed. Hugh Gray, Berkeley: University of California Press.

Benjamin, Walter (1969). Illuminations, New York: Schocken Books.

(2014). Fotoğrafinin Küçük Tarihi, çev. Barış Tanyeri, İstanbul: Altıkırkbeş Yayın.

Bryson, Norman (1983). Vision and Painting: The Logic of the Gaze, New Haven: Yale University Press.
Buckland, Gail (1980). Fox Talbot and the Invention of Photography, Boston: David R. Godine.

Comolli, Jean-Louis (1986). "Technique and Ideology: Camera, Perspective, Depth of Field”. Narrative, Apparatus, Ideology: A Film Theory Reader, ed. Philip Rosen, New York: Columbia University Press.

Crary, Jonathan (1988). "Modernizing Vision”. Vision and Visuality, ed. Hal Foster, Seattle: Bay Press.

(2010). Gözlemcinin Teknikleri: On Dokuzuncu Yüzyılda Görme ve Modernite Üzerine, çev. Elif Daldeniz, İstanbul: Metis Yayınları.

Descartes, René (2012). “Optics”. Images: A Reader, ed. Sunil Manghani, Arthur Piper ve Jon Simons, London: Sage.

Foucault, Michel (1995). Discipline and Punish: The Birth of the Prison, New York: Vintage Books.

Hannavy, John (ed.) (2008). Encyclopedia of Nineteenth-Century Photography, New York: Routledge.

Jay, Martin (1988). "Scopic Regimes of Modernity". Vision and Visuality, ed. Hal Foster, Seattle: Bay Press.

(1994). Downcast Eyes: The Denigration of Vision in TwentiethCentury French Thought, Berkeley: California University Press.

Kracauer, Siegfried (1997). Theory of Film: the Redemption of Physical Reality, Princeton, NJ: Princeton University Press.

Levin, David M. (1993). Modernity and the Hegemony of Vision, Berkeley, University of California Press

Marien, Mary W. (2006). Photography: A Cultural History, Upper Saddle River, NJ: Prentice Hall.

Mitry, Jean (2000). The Aesthetics and Psychology of the Cinema, çev. Christopher King, Bloomington: Indiana University Press.

Nadar, Félix (1978). "My Life as a Photographer", çev. Thomas Respensek. October 5: 6-28.

Panofsky, Erwin (2013). Perspektif: Simgesel bir Biçim, çev. Yeşim Tükel, İstanbul: Metis Yayınları.

Peirce, Charles S. (1998). "What is a Sign? (1894)”. The Essential Peirce: Selected Philosophical Writings, ed. Nathan Houser ve diğerleri, Bloomington and Indianapolis: Indiana University Press.

Rosalind E. Krauss (1985). The Originality of the Avant-Garde and Other Modernist Myths, Cambridge, MA: MIT Press.

Rose, Jacqueline (1986). Sexuality in the Field of Vision, London: verso.

Sontag, Susan (1990). On Photography, New York: Doubleday.

Walton, Kendall (1984). "Transparent Pictures: On the Nature of Photographic Realism.” Critical Inquiry, 11(2): 246-277. 